\title{
The Challenges in Undertaking English Speech Training Program at an Islamic Boarding School : A Study of Students' Perspectives
}

\author{
Bahrun Abubakar \\ bahrun.unm@gmail.com
}

HaryantoAtmowardoyo

haryanto@unm.ac.id

Chairil Anwar Korompot

chairilkorompot@gmail.com

State University of Makassar, Indonesia

\begin{abstract}
The objectives of this research were to find out (1)the students' perspective about the English Speech Training through the Muhadharah Program at IMMIM Putera Islamic Boarding School; (2) the most significant problems that challenge the students in undertaking English Speech Training through the Muhadharah Program; (3) the actions that the students already took in attempt to deal with the problems they had in undertaking the English Speech Training through the Muhadharah Program.This research employed descriptive qualitative research design. It applied purposive sampling technique. The participants of this research were two students, they are grade 2: 1 student and grade 6: 1 student. The data were collected by using interview and observation. The interview was used to gather the data about the students' perspectives on the English Speech Training through the Muhadharah Program at IMMIM Putera Islamic Boarding School, the challenges they faced and the solutions they took dealing with the English Speech Training through the Muhadharah Program. The result of research showed that (1) the perspectives of the students on the Muhadharah program in IMMIM Putera Islamic Boarding School are quite positive; (2) the most significant problems that challenge the students in undertaking the program are mostly related to the linguistic factors; peers' generated anxiety; monotonous design of the program; and speech by rote; (3) the solutive action taken by the students to tackle the problems in undertaking the Muhadharah program; preparing the speech materials and speech techniques. This is done in two ways: consulting to supervising teachers (done by junior students); preparing everything independently (done by senior students). The implications of this research are; (1) promoting a term to address a new speaking feature called "Speech by Rote"; (2) pesantren should recruit supervising teachers with good English command; (3) pesantren should vary the design of the program.
\end{abstract}

Keywords: Student of Islamic boarding school, English speech training, Challenges

\section{INTRODUCTION}

Public speaking has not been studied broadly by researchers around the world. Not many references can be found that discuss the nature of public speaking. Perhaps, that is because 
most people do not see the significance of conducting a research in the area of public speaking nature.

A number of studies have looked into public speaking. However, they focused on the context of psychological nature of it. They mostly studied about the anxiety of the speakers in delivering public speaking. While the researches that discussed about public speaking in the context of the learning process are not in a long list.

One of the few studies in this area was conducted by Otoshi and Heffernen (2008). They did a research to find the factors predicting effective oral presentations in EFL classrooms. They surveyed 304 undergraduate students at a large private university in Japan. Their study explores what factors EFL learners consider to be important when making presentations. In this study, a 30-item questionnaire was used to discover what components are considered to be important to learners in doing effective English presentations. The results indicate that the participants consider the following three factors as the major criteria for effective English oral presentations: clarity of speechand voice quality; correctness of language; and interaction with the audience.

In relation to the teaching of English public speaking in Islamic boarding school, there has been no research conducted that particularly studied about the teaching of English public speech through Muhadharah program. And this is a missing space that the writer expects to fill through this research.

Apart of English language teaching and training, public speaking teaching is not as easy as teaching other skills. It requires all parties' participation in supporting the effectiveness of the teaching or training. Brookhart (2003) stated that the students' point of view matters because of its effect on learning. Students' point of view can determine how they feel on the learning process, whether they find it interesting enough or not, well-organized or not, and effective enough or not.

By knowing the students' perspective towards the language teaching or training design they undertake, a better program can be developed and students' interest in taking part and succeeding in the program can be ensured and sustained.

\section{Research Questions}

Based on the background above, the research questions can be formulated are as follows:

1. What are the students' perspectives of the English Speech Training through the Muhadharah Program at IMMIM PuteraIslamic Boarding School?

2. What are the most significant problems that challenge the students in undertaking English Speech Training through the Muhadharah Program at IMMIM PuteraIslamic Boarding School?

3. What actions did the students take to deal with the problems they had in undertaking the English Speech Training through the Muhadharah Program at IMMIM PuteraIslamic Boarding School? 


\section{Research Methodology}

\section{Subjects}

The subjects of this research were the students of IMMIM Putera Makassar Islamic Boarding School in academic year of 2015/2016. They were from two classes, grade 2 and grade 6who were undertaking the Muhadharah Speech Training Program. The technique of gathering the sample was purposive sampling.

The researcher met the program supervisor and asked for two students to be interviewed. The researcher had decided certain criterions for the subjects of this research. And they were that the subjects should be strong students and they have very different backgound in term of the studying duration in the school to represent the junior year group and the senior year group.

\section{Instruments}

I applied descriptive qualitative research design. Nevertheless, the instruments of this research were as follows:

\subsection{Semi-Structured Interview}

In this research, the researcher provided a list of questions asking about how the students feel, think and see on the implementation of English Speech Training through the Muhadharah in IMMIM PuteraIslamic Boarding School, what kind of obstacles that the students meet during undertaking the training, and how did they deal with the problems.

When the researcher thought it was necessary to gather deeper and wider information about certain issue, the researcher asked questions that were unplanned before in order to elaborate and develop the information. This is called Unstructured Interview Model.

\subsection{Overt Participant Observation}

The researcher attended the Muhadharah program and saw how it run. While attending, the researcher crosschecked the data given by the interview subjects. The main focus of the researcher when attending the Muhadharah was to see whether the kinds of problem that appeared in the interview sessions really did happen during the activity.

\section{Procedure of Collecting Data}

In pesantren, as well as in IMMIM Putera Islamic Boarding School, there is commonly a speech training program that is called the Muhadharah. This program is designed to give a media for the students practicing and developing their skill and knowledge to deliver a speech in three languages, Bahasa Indonesia, Arabic and English.

The Muhadharah program is regularly conducted once or twice a week. There, certain students will deliver speeches while others will act as the spectators. The researcher asked permission from the school management to get access to come and observe how this program runs. After that, the researcher asked the program supervisor to pick two students to be interviewed. 
The researcher decided certain criterions for the subjects of this research. And they were that the subjects should be strong students and they have very different backgound in term of the studying duration in the school to represent the junior-year group and the senior-year group.

Based on the data gathered in the interview sessions, the researcher then did series of observation to crosscheck the data. In brief, the procedures of the data collection will be as follow:

A. The researcher asked permission to the IMMIM Putera Islamic Boarding School management to conduct a research in that institution

B. Then, the researcher did an observation to see how the program run and was managed.

C. After that, the researcher asked the program supervisors to pick two students to be the research subject based on certain criterions that the researcher had decided and then conducted interviews with the subjects separately to gather data. This was on a specific purpose that the subjects would represent the junior year group and the senior year group.

D. Finally, the researcher did series of observation to see how the Muhadharah program runs. The researcher crosschecked the data taken in the interviews.

4. Data Analysis

In analysing the data, I used descriptive analysis by categorizing the data from the interview findings. in this context, the categorization was based on the research questions of this research.

\section{Result and Discussion}

1. The students' perspectives of the English Speech Training through the Muhadharah Program at Islamic boarding school

a. Students' perception on the objectives of the Muhadharah program

All students share similar perspectives on the objectives of the school setting the Muhadharah for the students. The Muhadharah is a compulsary activity that all students have to undertake. Every student from any classes and any hostels has to attend the program as an audience, host, speaker or commentator.

1) To have the ability to speak up in public

This is shown on the transcription below:

“...ehm, pengasuh pesantren menginginkan kami para santri untuk lancar berbicara didepan khalayak umum. Yang kedua, dengan melakukan kegiatan Muhadhrah dengan berbahasa Inggris, pengasuh pesantren mengharapkan kita bisa berbicara dengan bahasa Inggris di banyak orang.."

[... um, the school management expects us, the students, to speak in public fluently. And also, by doing the Muhadharah in English, we are expected to have the ability to speak English at crowds]

2) To be able to express thoughts freely, directly and independently 
The school also expects all students to have the ability to speak up their thoughts without fear of making mistakes, being judged by others and without being nervous.

b. Students' perception on the design of the Muhadharah program

1) The program is well-designed

This is shown on the script below:

"...Kegiatan Muhadharah di pesantren saya dikemas dengan menarik."

[...the Muhadharah program in my school is design in an interesting way.]

2) The program is not well-designed

There is also a perception among students that the design of the Muhadharah is too convensional. There has been no variation from time to time and this situation has led into boredom to senior students.

c. Students' perception on the advantages of undertaking the Muhadharah program

1) How important the Muhadharah program for the students is

All subjects agree that the Muhadharah is an important program to undertake and it can be a helpful media for them to prepare to be qualified preachers. To state this point, some students directly argue that it is important while others mention it inplicitly. However, every student has similar perscpective that it is an important program.

2) What kind of knowledge do the students learn through the Muhadharah program Students who undertake the Muhadharah program can notice that throughout the training, they learn new vocabularies and certain terms and expressions about the dakwah.

3) What kind of skills do the students practice by through the Muhadharah program

The Muhadharah program, on the students' point of view, is a good media to drill language skills. They learn how to speak effectively and how to manage everything to convince the audience about a thing.

4) How much progress does the Muhadharah program do to the students

Generally, students realize that there is progress in the vocabulary mastery and public speaking skills

d. Students' perspectives on the factors that can determine the students' success in undertaking the Muhadharah program

1) Self esteem as a key factor to be succeed in undertaking the program

2) Strong will as another key factor to be succeed in undertaking the program

2. The most significant problems that challenge the students in undertaking the English Speech Training through the Muhadharah Program at Islamic boarding school

a. Perception that English is a difficult thing

The first problem that the students have in undertaking the training program is a perception that English is a difficult thing. Lots of students grow in non English environment and 
many of them are from remote areas where English is not an everyday thing to get along with.

This is shown on the transcription below:

“...masalah yang dihadapi kebanyakan santri ialah kebanyakan santri banyak yang belum siap dalam menyiapkan persiapan pidatonya pada saat giliran mereka karena merasa pidato bahasa Inggris ini, menurutnya susah. Baik dari segi bahasanya maupun pengucapan katanya, kata-kata bahasa Inggrisnya."

[...the problems that most students have is that most students are not ready in the speech preparation (not well prepared) when their turn comes as they think English speech is difficult. The language and also the pronunciation, the English words.]

This is similar to what Brookhart (2003) stated that the students' point of view matters because of its effect on learning. Students' point of view can determine how they feel on the learning process, whether they find it interesting enough or not, well-organized or not, and effective enough or not. And in relation to this, Picciano (2002) points out that students' perception may be the catalysts for continuing to pursue coursework and other learning opportunities. They become influencing factor that can take part in determining the following mass of effort that students can perform in improving their learning outcome. This is also supported by a research by Ellis (2008). She indicated five general areas of learners' beliefs that may affect the learning achievement, and the first of five beliefs is related to the students' belief in the difficulty of language learning.

\section{b. Linguistic Problems}

Many students have problems in the areas of pronunciation and vocabulary. The unique way of articulating English words seemed to trouble the students.

This is shown on the following transcription:

"Mmm, sama saja kayak kebanyakan santri. Yang pertama itu, pengucapan atau pronunciation bahasa Inggris itu membuat saya susah. Yang kedua, kosakata dalam bidang agama itu, jarang saya dengar."

[Hmm, similar to most students. The first is pronunciation. It made me into trouble. The second, (is) the vocabulary on theology (topics). I do not hear very often.]

The issue on this matter is that most students struggle to copycat the accent onf English native speakers which is barely impossible. This has also been a big concern by Ur (1996). He remind language learners not to push themselves to have perfect pronunciation and accent as the the native speakers perform. He pointed out, "It needs to be said at the outset that the main of pronunciation improvement is not to achieve a perfect imitation of a native accent, but simply to get the learner to pronounce accurately enough to be easily and comfortably comprehensible to other (competent) speakers..."

\section{c. Monotonous Format of the program}

The students who undertake the program are from all classes at the school. They are from six different grades. And because they do so, students possibly experience the same training method throughout the years. The problem occurs when the training program 
designed for all students from all grades is similar. Students have to experience similar training method time to time, year to year. In many ways, this can absolutely lead to boredom and it can end up with demotivation.

This is shown on the following script:

"Secara umum, masalah yang dihadapi kebanyakan santri dalam Muhadharah adalah kebosanan karena dari tahun ke tahun Muhadharahnya itu-itu saja. Seperti tidak ada inovasi dan motivasi untuk menjadi lebih baik."

[In general, the challenge that most students have is boredom since from year to year the Muhadharah stay similar. It seems to have no innovation and motivation to be improved.]

In relation to this issue, Nunan (2003) argues that variations in a language learning design are essential since the profiles and needs of each class are different. That is why, senior students must be provided with different training design which is customized referring to their profiles and needs.

\section{d. Peer Generated Anxiety}

One point that becomes a problem in undertaking the program is negative manners of other students towards the speakers. The audiences can ridicule the speakers during they are carrying out their speech. this generally happen when the audiences notice mistakes or errors in the speech delivery.

This is shown on the script below:

"Ehm, saya, yang biasa saya hadapi dalam pelatihan pidato bahasa Inggris adalah ocehan teman dan mereka yang merendahkan disaat kita melakukan kesalahan."

[Um, me, what I usually face in the English speech training is mates' ridicules and they disparage (us) when we make mistakes.]

This phenomenon can be viewed from two points of view. It can be taken as a negative thing as it can corrupt the speakers' focus and also can be taken as a practice of disrespect towards the speakers. However, it can be taken in a positive way in the context of that practice can be an indicator if the audiences actually pay a big attention to the speakers. And that makes them notice when the speakers make mistakes.

Actually, that energy can be transformed into positive way through Peer Assessment activity. By doing Peer Assessement, better involvement by other students can be achieved. And that is positive. This is pointed out by Race, Brown \& Smith (2005) who argue that the practice of peer assessment (PA) has been recognized as having possibly enormous benefits in terms of learning gain, and is increasingly being used in higher education to involve students more actively in the assessment process. Topping (1998) defined Peer Assessment as "an arrangement in which individuals consider the amount, level, value, worth, quality, or success of the products or outcomes of learning of peers of similar status".

e. Kinds of common mistakes that can lead to ridules 
In relation to peers' ridicules toward the speakers, there are mistakes that generally lead to that practice. Those mistakes are mispronunciation and code mixing. Sometimes, speakers pronounce certain words not in the right way. Another time, they want to say things but they do not know how to say them in English. For the audiences, it is noticable and when they do, many other students might spontanously ridicule the speaker.

Actually, this does not need to happen when everybody undestands that making mistakes is a part of the learning process. Hyland (2013) argues "All students make mistakes at various stages of their language learning. It is a part of the natural process they are going through and occurs for a number of reasons.

f. Speech by Rote

This is a surprising finding that has never come to the researcher's thought. The fact is most students are required to perform on the stage, talking and delivering a speech, but they have no idea what they talk about.

This is shown on the following script:

“... dalam pelatihan pidato bahasa Inggris kami hanya disuruh menghafal dan kami tidak memahami apa yang kami katakan ..."

[... in the English speech training, we are only told to memorize (the script) and we do not understand what we say ...]

The researcher would promote to name this phenomenon as "Speech by Rote" since there is no term to address this phenomenon in ELT discource. This term refers to the practice of memorizing a speech script, delivering it in public, but without understanding the meaning and the point of the speech itself.

3. The actions the students take to deal with the problems they had in undertaking the English Speech Training through the Muhadharah Program at Islamic boarding school

a. Drilling and Consulting to Supervising Teacher

One action that taken by the students in regards to deal with the problems they have in udertaking the Muhadharah program is drilling and consulting to supervising teachers. The role that the teachers play at this point is essential as they are the source of knowledge for the students. They help students with the language problems, and also with the public speaking skills.

This can be seen on the following script:

“... yang saya lakukan, dengan terus latihan, latihan terus. Kemudian, jika ada kata-kata yang dalam pidato tersebut yang menurut saya susah, saya akan tanyakan kepada ustad saya."

[... what I did, by kept practicing, again and again. Then when I met some words in my script that I considered to be difficult, I would ask my teacher.]

This is a bit irrelevant to what Murdibjono (1990) stated about the the factors of the failure of the teaching of English as a foreign language in Indonesia which are: (1) the size of the 
class; (2) the environment; (3) the quality of the teachers; (4) the time allotment for English; and (5) the student's motivation.

b. Preparing the speech concept independently and speech drilling

Another action is taken by other students. In this context, they independently do everything without bothering the supervising teachers. Generally, they develop ideas by themselves, finding the difficult English words in dictionary, and independently practice and drill at their own efforts.

This can be seen on the following script:

"Ehm, saya mengartikan pidato saya akan saya bawakan, saya mengulanginya beberapa kali dan saya mencoba dengan, saya mencoba mengulanginya dengan bahasa saya sendiri."

[Um, I translated my (speech) script that I will deliver, I practiced several times and I tried to do it with my own words.]

This is commonly done by more senior students. This is relevant to what Eloff (2004) argued. She stated that individuals older than 12 years old, gradually seek for independence. They begin to form self-identity and change their view of themselves, environment and everything else.

c. Perception on how successful or effective the actions taken by the students are In regard to this matter, all students agree that the actions they take to deal with the problems in undertaking the program are successful and are helpful for them. They feel that they managed to overcome the barriers that hamper most students including themselves.

d. Perceptions on the chance of other students to follow the successful students

About the chance of other students to copycat what they did, they share similar argument that they have positive perspectives that any students can do the things like them. They argued that what they did was not a special thing and so, anyone else can also do and benefit the same way.

\section{Other research findings}

a. Students' suggestions for future improvement of the Muhadharah program

1) Idea to vary the venue and audience background

Some students argue that having a chance to carry out a speech with new audience and at a new place will be nice. This avoids boredom and can give authentic experience on being among strangers. This is relevant to what Nunan (2003) argues that variations in a language learning design are essential since it can maintain and boost motivation as the students meet a new challenge and have a new colour.

This is seen on the following script:

“...saya menyarankan, untuk mengirim santri-santrinya ke sekolah yang mengajarkan didalamnya bahasa Inggris."

[... I suggest to send the students (to deliver the English speech) to the schools where English is taught.] 
2) Idea to provide a stage-like set up for the program venue

Some students propose to have the program as authentic as it can become. And they think that by providing a stage where the speakers can really stand up before audience, everything will be more exciting.

This is seen on the script below:

“...berbicara diatas tempat yang cukup, agak tinggi daripada audiens yaitu teman-teman kita agar itu melatih kita untuk supaya terbiasa dengan keadaan diluar yang membawa pidato itu lebih tinggi daripada audiensnya."

[... speak at a high enough point, a little higher than the audiens who are our friends in order to train us to get used to with the situation outside where (the speakers) deliver the speech at a higher standing point than the audiens.]

\section{3) Suggestion to peers}

Most students recommend their peers to take the program seriously. This mental attitude is important as it can determine the level of progress they can perform from time to time. They believe that only serious students who can benefit from the the program.

This is shown on the script below:

"saran saya, agar setiap santri yang ingin menampilkan pidatonya agar mempelajarinya terlebih dahulu dan mempelajarinya di pembina masing-masing supaya kegiatan pidato di Muhadharah berjalan dengan lancar tanpa ada yang harus diperbaiki."

[my suggestion, to all students who will perform their speech to learn it beforewards and learn it (consult) to the teacher (hostel supervisor) in order to make the Muhadharah run smoothly without anything to correct.]

4) Idea to regularly contest the speakers

Thes students think it can give a reason for everybody to give up everything and to do lots of efforts as each student look out for number one.

This is shown on the script below:

“... saya menyarankan agar diberikan hadiah kepada mereka yang mempunyai ceramah yang terbaik pada minggu itu."

[... I suggest to give presents for those who have the best speech on the week.]

b. Students' perception on the quality of the Muhadharah program final output

1) The final output is predicted to be satisfactory

Most junior students believe that what they learn from the Muhadharah program will be enough to prepare them to be preachers to do the dakwah job in English speaking countries.

This is shown on the script below:

"ehm, menurut saya, ehm, sudah cukup untuk menyiapkan para santri karena pelatihan Muhadharah ini sudah ehm, menyiapkan contoh bagaimana keadaan diluar sana, diluar pesantren seperti ditonton oleh banyak orang yang dianggap sebagai orang-orang asing." [uhm, in my point of view, it is enough to prepare the students (to be preachers in foreign/English speaking countries) since the Muhadharah training has already uhm, 
provided samples on the things out there, being outside the boarding school such as being watched by lots of people taken into mind as foreigners.]

2) The final output of the program is predicted to be unsatisfactory

More seniorstudents do not think that what they learn throughout the Muhadharah program will be enough. They believe that there are lots of other things they have to fix before they can really be ready for the dakwah job in English speaking countries.

This is shown on the script below:

“...menurut saya, pelatihan pidato bahasa Inggris melalui kegiatan Muhadharah di pesantren saya tidak, masih belum cukup untuk dikirim kenegara-negara berbahasa Inggris seperti Canada, US, UK dan lain-lain karena pada pidato bahasa Inggris ini kita hanya diajarkan untuk menghafal dan kesalahan-kesalahannya adalah pronunciation kami banyak-banyak kesalahannya. Bila kita membawanya ke US, UK, mungkin mereka tidak akan mengerti apa yang kita bicarakan. Begitu."

[In my perspective, the English speech training through the Muhadharah program at my school not, still not enough to send (the students) to English speaking countries like Canada, US, UK and others as on the English speech (training), we are merely told to memorize and the mistakes (are) our pronunciation got many errors. When we take it (pronunciation) to US, UK, they probably will not undertand what we talk about.]

\section{CONCLUSION}

This research is an endeavor to analyze the students' perspectives on the challenges in undertaking English speech training program at Islamic boarding school.. Based on the findings and discussion in the previous one, I put forward the following conclusions based on the the research questions of this research:(1) The perspectives of the students on the Muhadharah program in IMMIM PuteraIslamic Boarding School are quite positive. They notice that there are advantages they can get throughout the program. They can learn new vocabulary, know how to be good speakers and grow as independent and confident individuals. However, the students pointed out several things to improve the program. They mentioned about sending them to other schools so they they can learn to meet new people and new places and the idea of presenting gifts for the best speakers at every time; (2) The most significant problems that challenge the students in undertaking the program are mostly related to the language. It is completely undertandable when they do since English is not their mother tongue. Most problems deal with the pronunciation and the unfamiliar terms. Another point is on the program design that is systemically similar from year to year. This has led to boredom and demotivation of the senior students. The last point is on the disparament by other students that the speakers have to experience. This mostly happen when they make mistakes, such as mispelling the words and mixing the speech with Indonesian; (3) The actions taken by the students to overcome the problems they have in undertaking the Muhadharah program are related to the language. Some students meet the teachers to get help with their speech preparation, while some others manage to prepare everything independently. Junior students tend to get more help from the teachers and senior students become more independent to do the things by themselves. 


\section{REFERENCE}

Anjaniputra, Agung Ginanjar. 2013. Teacher's Strategies In Teaching Speaking To Students At Secondary Level. Journal Of English And Education, 1(2), 1-8 1

Bin Tahir, S. Z. 2011. The Effectiveness of English Teaching Method at Pesantren IMMIM of Makassar. JUPITER Journal UPT Lib of University of Hasanuddin.Vol IX No. 1. November tahun 2011. No. ISSN: 1693-5535.

Bin Tahir, Saidna Zulfiqar A. 2015. Multilingual Teaching And Learning At Pesantren. UniversitasIqra Buru.

Docan-Morgan, Tony and Schmidt, Thomas. 2012. Reducing Public speaking Anxiety for Native and Non-Native English Speaker: The Value of Systematic Desensitization, Cognitive Restructuring, and Skills Training. Journal of Cross-Cultural Communication, Volume 8, Number 5.

Ellis, Rod. 2008. Learner Beliefs and Language Learning. Asian EFL Journal, Vol. 10, No. 4: Conference Proceedings

Hsiu-Chinh, Sheu. 2009. EFL Children's Views on English Picture Story Books. The Asian EFL Journal Quarterly, December 2009, Volume 11, Issue 4

Hughes, A. 2003. Testing for Language Teachers. ( $2^{\text {nd }}$ ed). Cambridge: Cambridge University Press.

Hyland, Ken. 2013. Innovation and Change in Language Education. New York: Routledge.

Marshal, C., \& Rossman, G.B. 2006. Designing Qualitative Research. (4th ed.). USA: Sage Publications, Inc.

Otoshi, Junko and. Heffernen, Neil. 2008. Factors Predicting Effective Oral Presentation in EFL Classrooms. The Asian EFL Journal, March, Volume 10, Number 1.

Picciano, Anthony G. 2002. Beyond Student Perceptions: Issues Of Interaction, Presence, And Performance In An Online Course. JALN Volume 6, Issue 1 - July 2002

Wang, Hong. 2008. Language Policy Implementation: A Look at Teachers' Perceptions. Asian efl journal, Professional Teaching Articles. August 2008

White, Eddy. 2009. Student Perspective of Peer Assessment for Learning in a Public speaking Course. The Asian EFL Journal, January, Volume 33. 
Williamson, Lynette. (Ed).2004. Speaking Across the Curriculum: Practical Ideas for Incorporating Listeningand Speaking into the Classroom. New York. International debate association education.

Yaikhong, Kriangkrai and Usaha, Siriluck. 2012. A Measure of EFL Public speaking Class Anxiety: Scale Development and Preliminary Validation and Reliability. Canadian Center of Science and Education, Volume 5, Number 12. 